\title{
ANALISIS PERUBAHAN PARTAI POLITIK PEMENANG PEMILU DI INDONESIA
}

\author{
Handy Martinus \\ Marketing Communication, Faculty of Economic and Communication, BINUS University \\ Jl. KH Syahdan No 9, Kemangisan-Palmerah, Jakarta Barat 11480 \\ handy.martinus@binus.ac.id
}

\begin{abstract}
By three elections in Indonesia, the pattern seen is a change in a very significant political force. It changed not only the party in the first position, but also a different party: three elections produced three different parties that received the most votes. Major political changes in Indonesia have been coloring since the reformation in 1998. The first change occurred in the 1999 election. PDIP evicted Golkar that has ruled for more than 30 years claiming an absolute majority. Then in the 2004 election, the strength of the party with the most votes moved to Golkar. In 2009, a major change occurred again. Top position was taken by Democrats. This article is a study using secondary data from a survey conducted by the Indonesian Survey Institute (LSI) during the period 1 to 12 February 2012 with the population of all Indonesian citizens who have the rights to vote in elections when the survey was conducted. Number of samples taken ranged up to 2,050. Based on the sample, it is estimated margin of error of $+/-2.2 \%$ at the $95 \%$ confidence level. It is concluded that the political change will continue in the 2014 election along with the negative sentiments from Indonesian people against politics and law enforcement today. Election results earlier in some parts of Indonesia showed a progressive trend increasing number of non-voters and swing voters. NasDem and Gerindra are quite prominent in voter mobilization through the air via mass media. Both attract Democrats' swing voters whom are middle-class which are more intensively following the national news.
\end{abstract}

Keywords: election, politic party, swing voter

\section{ABSTRAK}

Dari pengalaman tiga kali Pemilu di Indonesia, pola yang terlihat adalah perubahan kekuatan politik secara sangat berarti. Bukan hanya berganti partai pada posisi pertama, tetapi berganti dengan partai berbeda: tiga kali pemilu menghasilkan tiga partai berbeda yang mendapat suara terbanyak. perubahan politik besar telah mewarnai Indonesia sejak reformasi bergulir tahun 1998. Perubahan pertama terjadi lewat Pemilu 1999. Golkar yang berkuasa sepanjang 30 tahun lebih dengan klaim suara mayoritas mutlak digusur PDIP. Kemudian pada Pemilu 2004, kekuatan partai dengan suara paling besar berpindah ke Golkar. Pada 2009, perubahan besar kembali terjadi. Posisi teratas diambil alih oleh Demokrat. Penelitian menggunakan data sekunder hasil survei yang dilakukan oleh Lembaga Survei Indonesia (LSI) dalam kurun periode 1-12 Februari 2012 dengan populasi seluruh warga negara Indonesia yang punya hak pilih dalam pemilihan umum ketika survei dilakukan. Jumlah sampel yang diambil berkisar sampai 2.050. Berdasarkan jumlah sampel, diperkirakan margin of error sebesar +/-2.2\% dengan tingkat kepercayaan 95\%. Disimpulkan bahwa perubahan politik ini akan berlanjut pada Pemilu 2014 seiring dengan semakin negatifnya sentimen rakyat terhadap keadaan politik dan penegakkan hukum Indonesia sekarang ini. Hasil pemilukada silam di beberapa wilayah Indonesia menunjukkan tren progresif meningkatnya jumlah yang tidak memilih dan juga swing voter. NasDem dan Gerindra cukup menonjol dalam mobilisasi pemilih lewat udara via media massa. Kedua partai tersebut menarik swing voter Demokrat yang berlatar belakang kelas menengah yang lebih intensif mengikuti berita nasional.

Kata kunci: pemilu, partai politik, swing voter 


\section{PENDAHULUAN}

Secara historis, perubahan politik besar telah mewarnai Indonesia sejak reformasi bergulir tahun 1998, setidaknya jika observasi dibatasi pada partai yang mendapat dukungan rakyat paling banyak dan menjadi kekuatan utama dalam pemerintahan. Perubahan pertama terjadi lewat Pemilu 1999. Golkar yang berkuasa sepanjang 30 tahun lebih dengan klaim suara mayoritas mutlak digusur PDIP, dan Habibie digantikan Abdurrahman Wahid kemudian Megawati.

Kemudian pada Pemilu 2004 dukungan pada PDIP anjlok hampir separuhnya (dari 34\% menjadi 18.5\%). Kekuatan partai dengan suara paling besar kemudian berpindah ke Golkar walaupun Golkar sendiri dalam Pemilu 2004 mengalami penurunan suara, dari 23\% pada 1999 menjadi 22\% pada 2004. Perubahan politik kepartaian pada 2004 lebih ditandai oleh kemunculan dua partai baru yang mendapat suara signifikan, yaitu Demokrat (7.4\%) dan PKS (7\%) daripada posisi Golkar dengan suara paling banyak. Golkar pada 2004 lebih buruk dari 1999.

Pada 2009 perubahan besar kembali terjadi. Posisi teratas diambil alih oleh Demokrat. Golkar merosot tajam dari 22\% menjadi 14\%. Demikian juga PDIP dan partai-partai lain mengalami hal sama selain PKS.

Dari pengalaman tiga kali Pemilu pola yang terlihat adalah perubahan kekuatan politik secara sangat berarti. Bukan hanya berganti partai yang pada posisi pertama, tetapi berganti dengan partai berbeda. Tiga kali pemilu menghasilkan tiga partai berbeda yang mendapat suara terbanyak.
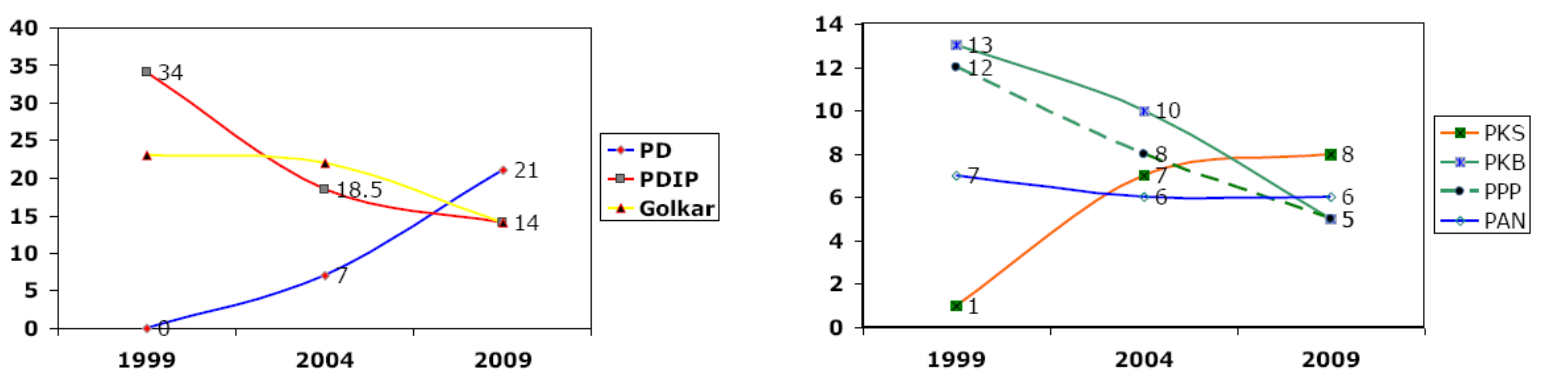

Gambar 1 Tren Hasil Pemilu (\%)

Sumber: rilis data KPU

Apakah perubahan ini baik atau buruk bagi proses pematangan politik Indonesia? Bila rakyat menilai politik sekarang buruk, legitimate kalau kemudian perubahan harus terjadi. Apakah perubahannya ke arah yang lebih baik? Bisa ya, bisa tidak. Yang pasti dari hasil yang ada, rakyat Indonesia sangat terbuka terhadap perubahan politik sebagaimana ditunjukan dalam tiga kali pemilu sebelumnya. Keterbukaan rakyat ini bisa dilihat sebagai kesempatan (opportunity) bagi perbaikan. Sedangkan perbaikan itu sebagian besar ditentukan oleh elite politik, bukan oleh rakyat. Pertanyaannya, apakah ada peluang bagi perubahan politik kepartaian pada 2014 nanti?

\section{METODE PENELITIAN}

Penelitian ini menggunakan data sekunder hasil survei yang dilakukan oleh Lembaga Survei Indonesia (LSI) dalam kurun periode 1-12 Februari 2012 dengan populasi seluruh warga negara Indonesia yang punya hak pilih dalam pemilihan umum, yakni mereka yang sudah berumur 17 tahun atau lebih, atau sudah menikah ketika survei dilakukan. Jumlah sampel yang diambil berkisar hingga 
2.050. Berdasar jumlah sampel ini, diperkirakan margin of error sebesar $+/-2.2 \%$ pada tingkat kepercayaan 95\%. Responden terpilih diwawancarai lewat tatap muka oleh pewawancara yang telah dilatih. Satu pewawancara bertugas untuk satu desa/kelurahan yang terdiri hanya dari 10 responden. Quality control terhadap hasil wawancara dilakukan secara acak sebesar 20\% dari total sampel oleh supervisor dengan kembali mendatangi responden terpilih (spot check). Dalam quality control tidak ditemukan kesalahan berarti. Waktu wawancara lapangan pada 1-12 Februari 2012.

Prosedur yang dilakukan dalam pemilihan sampel adalah prosedur Multistage Random Sampling dengan pembagian sebagai berikut. Stratifikasi 1: populasi dikelompokan menurut provinsi, dan masing-masing provinsi diberi kuota sesuai dengan total pemilih di masing-masing provinsi. Stratifikasi 2: populasi dikelompokan menurut jenis kelamin 50\% laki-laki dan 50\% perempuan. Stratifikasi 3: populasi dikelompokkan ke dalam kategori yang tinggal di pedesaan (desa, 60\%) dan perkotaan (kelurahan, 40\%). Cluster 1: di masing-masing provinsi ditentukan jumlah pemilih sesuai dengan populasi pemilih masing-masing provinsi. Atas dasar ini, dipilih desa dan kelurahan secara random sebagai primary sampling unit. Jumlah desa atau kelurahan tergantung jumlah pemilih di masing-masing provinsi. Ditetapkan, setiap desa dipilih 10 pemilih (5 laki-laki dan 5 perempuan) secara random. Jika di Jawa Barat persentase pemilih 17\% dan di NTB 2\%, di Jabar dipilih 17 desa/kelurahan dan di NTB dipilih hanya 2 desa/kelurahan, dst. Cluster 2: di masing-masing desa terpilih, kemudian didaftar populasi RT atau yang setingkat. Kemudian dipilih secara random 5 RT dengan ketentuan di masing-masing RT akan dipilih secara random dua keluarga. Cluster 3: di masing-masing RT terpilih, populasi keluarga didaftar, kemudian dipilih secara random 2 keluarga. Di masing-masing keluarga terpilih, kemudian didaftar seluruh anggota keluarga yang punya hak pilih, laki-laki atau perempuan. Kemudian dipilih secara random siapa yang akan menjadi responden di antara mereka. Jika pada keluarga pertama yang dipilih adalah responden perempuan, pada keluarga berikutnya harus laki-laki.

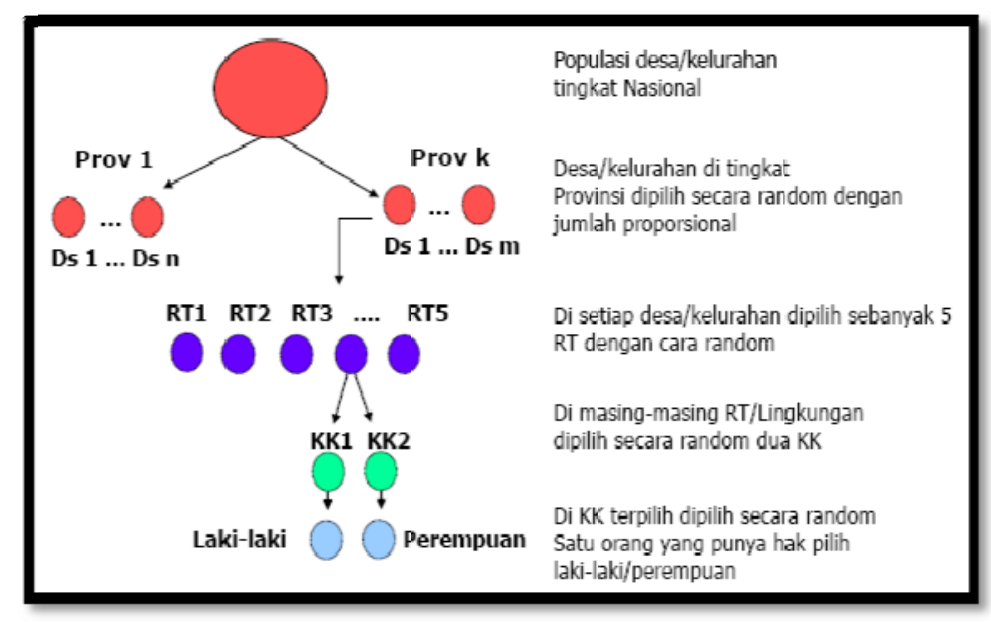

Gambar 2 Flowchart Penarikan Sample

\section{HASIL DAN PEMBAHASAN}

Berdasarkan metode penelitian, maka berikut ditampilkan profil demografi responden dan juga data demografi nasional sebagai pedoman dalam pengambilan sampel yang mengacu pada data dari Badan Pusat Statistik (BPS). 
Tabel 1 Profil Demografi Responden

\begin{tabular}{|c|c|c|}
\hline KATEGORI & SAMPEL & BPS \\
\hline \multicolumn{3}{|c|}{ GENDER } \\
\hline Laki-laki & 50.0 & 50.0 \\
\hline Perempuan & 50.0 & 50.0 \\
\hline \multicolumn{3}{|c|}{ DESA-KOTA } \\
\hline Pedesaan & 60.5 & 59.4 \\
\hline Perkotaa & 39.5 & 40.6 \\
\hline
\end{tabular}

\begin{tabular}{|c|c|c|}
\hline KATEGORI & SAMPEL & BPS \\
\hline \multicolumn{3}{|c|}{ AGAMA } \\
\hline Islam & 89.9 & 88.2 \\
\hline Katolik/Protestan & 7.0 & 8.9 \\
\hline Lainnya & $\overline{3.1}$ & 2.9 \\
\hline \multicolumn{3}{|c|}{ ETNIS } \\
\hline Jawa & 40.2 & 41.6 \\
\hline Sunda & 17.4 & 15.4 \\
\hline Melayu & 5.9 & 3.4 \\
\hline Madura & 3.7 & 3.4 \\
\hline Bugis & 3.4 & 2.5 \\
\hline Betawi & 1.8 & 2.5 \\
\hline Minang & 2.7 & 2.7 \\
\hline Lainnya & 24.8 & 28.5 \\
\hline
\end{tabular}

Tabel 2 Demografi Nasional

\begin{tabular}{|c|c|c|}
\hline KATEGORI & SAMPEL & BPS \\
\hline \multicolumn{3}{|c|}{ PROVINSI } \\
\hline NAD & 2.0 & 2.0 \\
\hline SUMATERA UTARA & 5.9 & 5.8 \\
\hline SUMATERA BARAT & 2.0 & 2.1 \\
\hline RIAU & 2.0 & 2.2 \\
\hline JAMBI & 1.5 & 1.3 \\
\hline SUMATERA SELATAN & 3.4 & 3.3 \\
\hline BENGKULU & 1.0 & 0.8 \\
\hline LAMPUNG & 3.4 & 3.3 \\
\hline BANGKA BELTUNG & 0.5 & 0.5 \\
\hline KEPULAUAN RIAU & 0.5 & 0.6 \\
\hline DKI JAKARTA & 3.4 & 3.3 \\
\hline JAWA BARAT & 17.1 & 17.2 \\
\hline JAWA TENGAH & 14.6 & 14.8 \\
\hline DI YOGYAKARTA & 1.5 & 1.5 \\
\hline JAWA TIMUR & 16.6 & 16.4 \\
\hline BANTEN & 3.9 & 4.1 \\
\hline
\end{tabular}

\begin{tabular}{|l|c|c|}
\hline \multicolumn{1}{|c|}{ KATEGORI } & \multicolumn{1}{|c|}{ SAMPEL } & BPS \\
\hline \multicolumn{2}{|c|}{ PROVINSI } \\
\hline BAL & 1.5 & 1.5 \\
\hline NTB & 2.0 & 2.0 \\
\hline NTT & 2.0 & 2.0 \\
\hline KALMANTAN BARAT & 2.0 & 1.9 \\
\hline KALMANTAN TENGAH & 1.0 & 0.9 \\
\hline KALMANTAN SELATAN & 1.5 & 1.5 \\
\hline KALMANTAN TIMUR & 1.5 & 1.4 \\
\hline SULAWESI UTARA & 1.0 & 1.0 \\
\hline SULAWESI TENGAH & 1.0 & 1.1 \\
\hline SELAWESI SELATAN & 3.4 & 3.4 \\
\hline SULAWESI TENGGARA & 1.0 & 0.9 \\
\hline GORONTALO & 0.5 & 0.4 \\
\hline SULAWESI BARAT & 0.5 & 0.5 \\
\hline MALUKU & 0.5 & 0.6 \\
\hline MALUKU UTARA & 0.5 & 0.5 \\
\hline PAPUA & 1.0 & 1.2 \\
\hline IRJABAR & 0.5 & 0.3 \\
\hline
\end{tabular}

Dari responden yang telah dipilih, kemudian dilakukan wawancara dengan memberikan beberapa pertanyaan mengenai kondisi Indonesia secara umum, meliputi keadaan politik nasional, penegakan hukum dan keadaan ekonomi nasional. Hasil wawancara adalah sebagai berikut.

Bagaimana Ibu/Bapak melihat keadaan politik nasional sekarang? Sangat baik, baik, sedang, buruk atau sangat buruk?

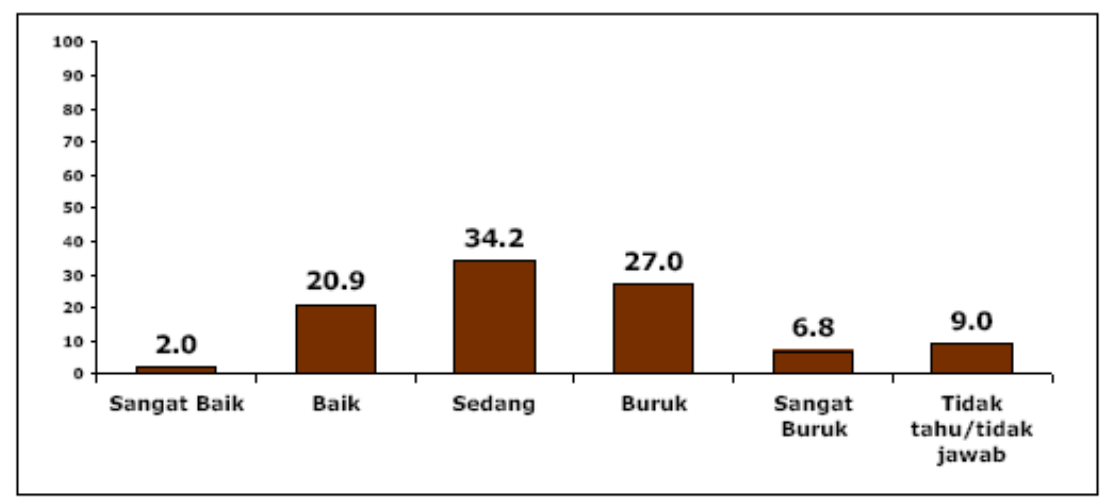

Gambar 3 Kondisi Politik secara Nasional Sekarang (\%) 


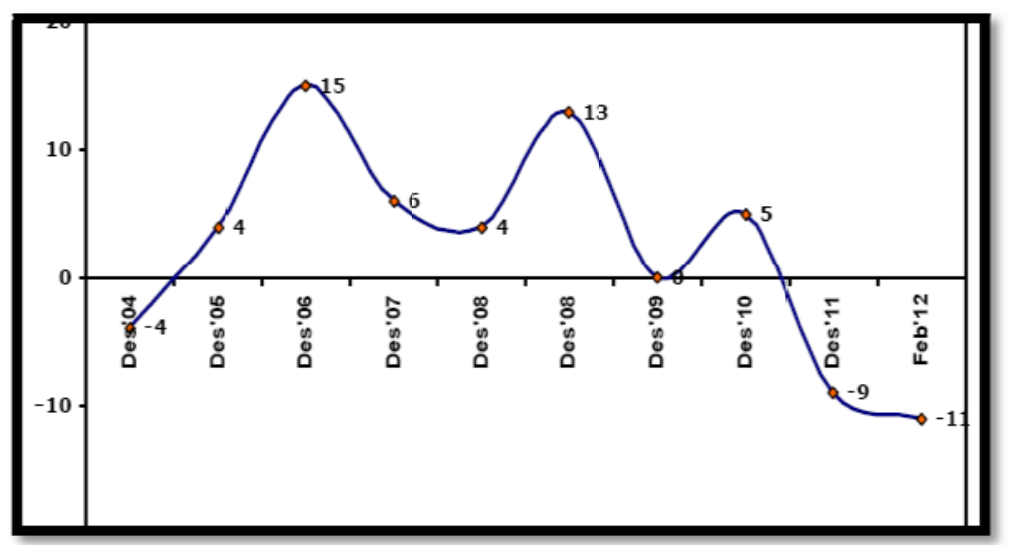

Gambar 4 Tren Keadaan Politik Nasional (\%)

Bagaimana Ibu/Bapak melihat keadaan penegakan hukum secara nasional sekarang? Sangat baik, baik, sedang, buruk atau sangat buruk?

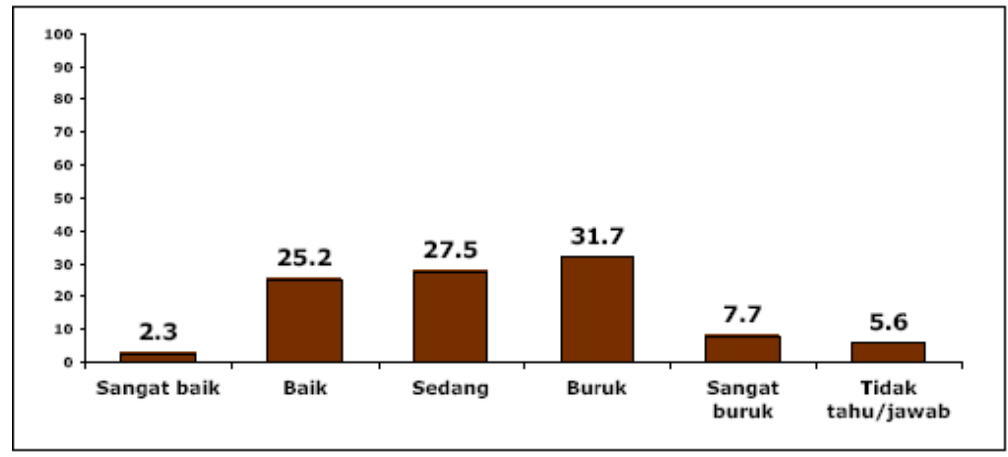

Gambar 5 Kondisi Penegakan Hukum secara Nasional Sekarang (\%)

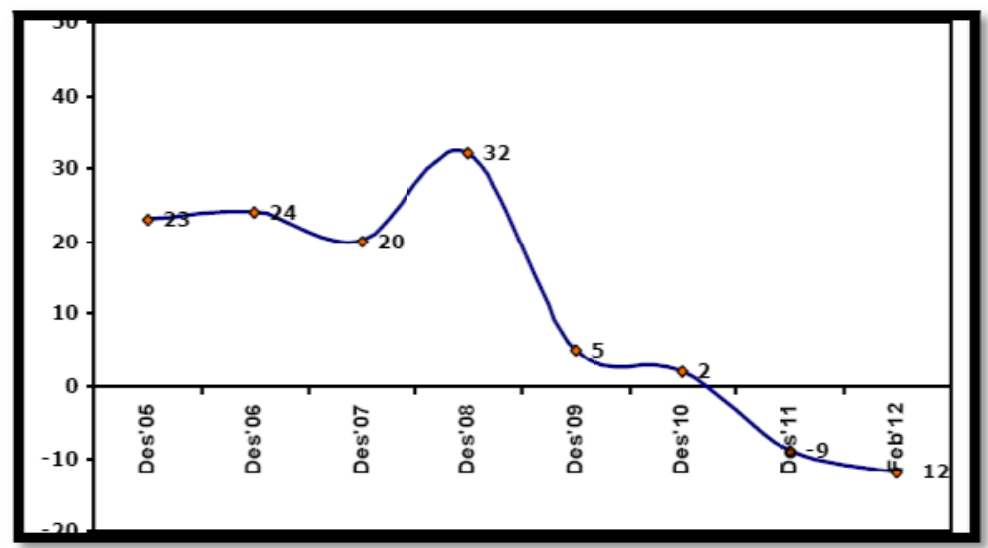

Gambar 6 Tren Kondisi Penegakan Hukum (\%)

Berdasarkan hasil pada Gambar 3 dan Gambar 4, dapat diuraikan bahwa penilaian rakyat terhadap kondisi politik nasional secara umum saat survei dilakukan menunjukkan lebih banyak yang mengatakan buruk atau sangat buruk dibanding yang mengatakan sebaliknya, baik atau sangat baik. Memang banyak yang mengatakan hanya "sedang”, yang berarti belum baik. 
Jika analisis difokuskan pada respons "baik" atau "sangat baik" dan "buruk" atau "sangat buruk" secara longitudinal, maka terlihat trend yang menunjukkan bahwa rakyat menilai politik nasional makin buruk, bukan makin baik. Penilaian buruk atau negatif pada politik nasional mulai terjadi pada setahun terakhir ini, 2011-2012. Sebelumnya, lebih banyak yang menilai politik nasional baik daripada yang menilai buruk. Hasil sama diperoleh untuk penilaian rakyat terhadap penegakan hukum.

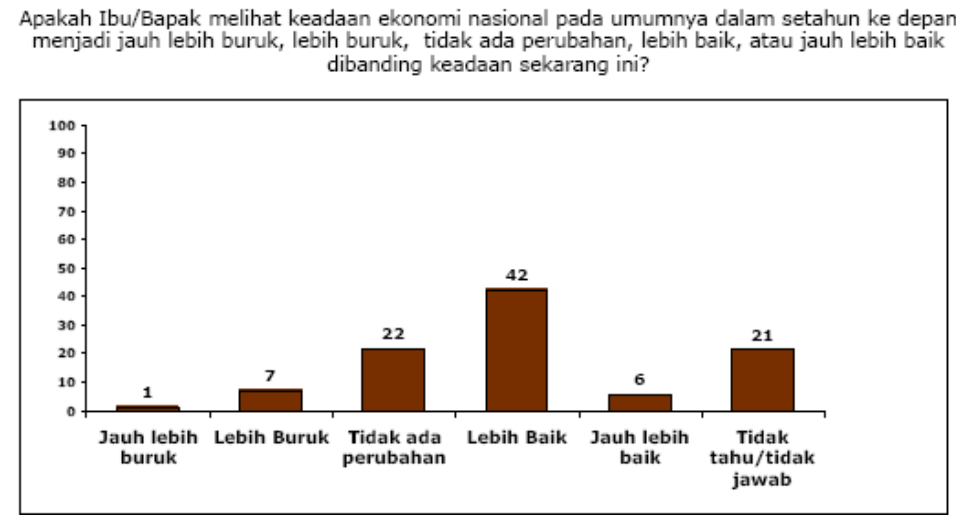

Gambar 7 Kondisi Ekonomi Nasional Setahun ke Depan Dibanding Sekarang (\%)

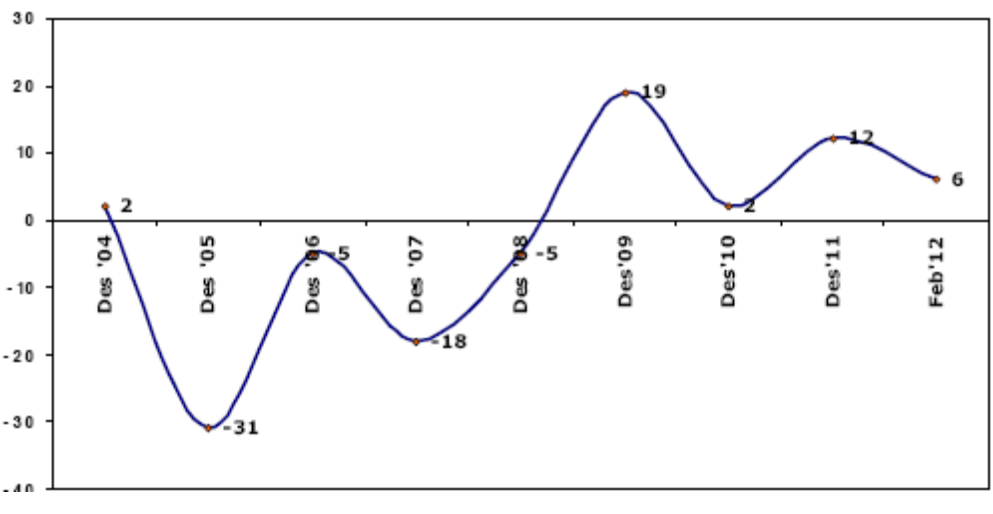

Gambar 8 Tren Keadaan Ekonomi Nasional (\%)

Yang menarik, rakyat secara umum cenderung lebih positif dalam melihat keadaan ekonomi nasional sekarang. Tren juga menunjukan semakin positif dan semakin optimis. Ini sesuai dengan penilaian ekonom pada umumnya atas kondisi ekonomi nasional sekarang ini. Kecenderungan menurunnya penilian positif terhadap politik nasional dan penegakan hukum sudah mulai terlihat di akhir 2009, ketika Pansus Century terbentuk, kemudian skandal Nazaruddin dkk. pada 2011 hingga sekarang. Penilaian rakyat terhadap politik yang negatif tersebut merupakan basis sosial bagi perubahan politik pada Pemilu 2014.

Ada situasi yang berubah jika melihat partai-partai peserta pemilu tahun 2014 mendatang. Bermunculan beberapa partai baru yang menawarkan perubahan, sebut saja Gerindra dan Nasdem. Sebuah prestasi menjadi satu-satunya partai politik baru yang lolos dalam seleksi administratif maupun faktual Komisi Pemilihan Umum (KPU) untuk ikut serta Pemilu 2014 mendatang. Partai Nasdem tak mengakuisisi, membeli, maupun mengambil alih, badan hukum partai lain agar mulus menuju Pemilu 2014. Partai yang kini dipimpin Surya Paloh berjuang sendiri memenuhi segala persyaratan yang ditetapkan Komisi Pemilihan Umum (KPU) agar lolos menjadi peserta pemilu. 
Meski sudah lolos dari lubang jarum seleksi peserta Pemilu 2014, jalan Partai Nasdem untuk berdiri di atas panggung politik nasional masih panjang. Partai Nasdem tentunya tidak ingin hanya menjadi partai pemanis pemilu mendatang. Partai ini ingin bersaing dengan sembilan parpol lain yang sudah merasakan nikmatnya kursi di DPR.

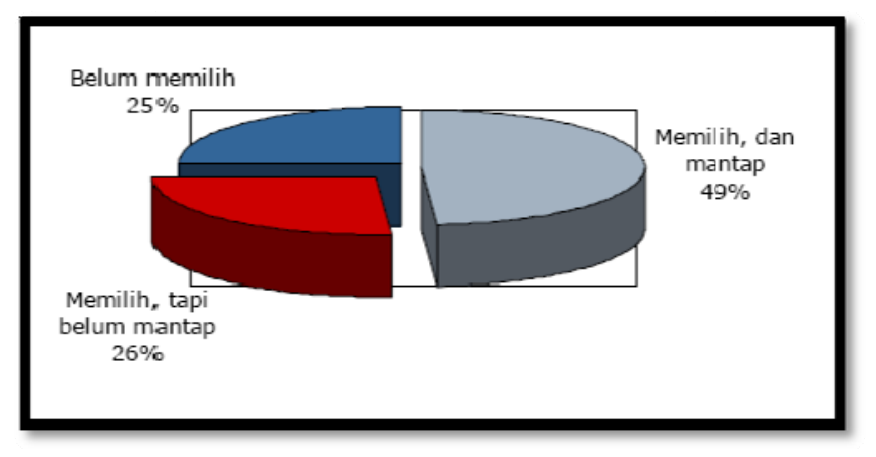

Gambar 9 Keputusan Memilih Responden (\%)

Dari sampel yang ada, juga tidak luput dari pertanyaan mengenai preferensi pemilih dalam memutuskan partai yang akan dipilih. Hasilnya seperti dalam Gambar 9, mayoritas $49 \%$ telah menyatakan memilih dan mantap. Namun, jumlah yang tidak sedikit yaitu 25\% Responden menyatakan belum memilih, $26 \%$ responden menyatakan telah memilih namun belum mantap. Jika dijumlah responden yang belum memilih dan telah memilih tetapi belum mantap menghasilkan angka $51 \%$.

Ini mengindikasikan bahwa ada sekitar separuh dari populasi pemilih yang menuntut partai agar bisa lebih meyakinkan mereka, atau menuntut perbaikan kinerja partai. Partai-partai yang terlihat sudah banyak melakukan sosialisasi (iklan di media, dan berbagai atribut) dalam dua tahun terakhir nampaknya belum banyak meyakinkan sebagian besar calon pemilih. Semua ini merupakan tantangan dan peluang bagi peningkatan perolehan suara partai yang bekerja keras dan meyakinkan, termasuk partai-partai menengah, partai-partai kecil yang belum punya kursi di DPR, atau partai-partai baru yang akan ikut berlaga dalam pemilu 2014 nanti. Semua ini membuka peluang bagi partai-partai untuk bekerja keras dengan meningkatkan kinerja yang lebih baik.

Sepanjang 2013 akan digelar tidak kurang dari 152 pemilihan umum kepala daerah. Sebanyak 103 pemilukada sudah dijadwalkan waktunya yang terdiri dari 12 provinsi, 67 kabupaten, dan 24 kota. Dari beberapa pemilukada yang sudah terselenggara di beberapa kota dan provinsi, muncul fenomena menarik. Fenomena itu adalah terus merosotnya partisipasi masyarakat dalam beberapa pemilukada dan 'partai golput' kerap meraih kemenangan mutlak.

Hasil pemilukada silam di beberapa wilayah Indonesia menunjukkan tren progresif meningkatnya jumlah yang tidak memilih. Pada pemilukada DKI putaran kedua yang dimenangkan Jokowi-Ahok, angka golput mencapai 33,5 persen. Pemilukada Sulsel pada 22 Januari 2013 silam mencatat partisipasi golput mencapai 31,6 persen. Bahkan total perolehan kelompok golput ini lebih besar dari total perolehan pasangan pemenang pemilukada. Di Jabar pasangan Aher-Demiz memenangkan pemilukada dengan meraih 20,04 persen suara. Namun kelompok golput lebih tinggi yaitu 36,26 persen atau setara dengan 11.786.221 jiwa.

Pada pemilukada Sumut silam, berdasarkan penghitungan suara yang dilakukan KPU, tingkat partisipasi pemilih hanya 48,50 persen. Dengan demikian, angka yang tidak ikut memilih mencapai 51,50 persen (detiknews, 15/3/2013). Angka golput ini jauh di atas perolehan suara pemenang GatotEry yang hanya meraih 33,84 persen. Itu berarti pasangan-pasangan pemenang pemilukada ini 
didukung oleh minoritas, bukan mayoritas. Tingginya tingkat golput ini sejalan dengan kecenderungan makin melemahnya tingkat kepercayaan masyarakat kepada sistem demokrasi-kapitalisme, instrumen pendukung dan pilar-pilarnya baik lembaga eksekutif, yudikatif dan legislatif. Golput ini didominasi oleh pemilih usia kurang dari 32 tahun yang melek informasi dan politik.

Secara teoretis, swing voter (Mujani, 2012) terjadi karena ikatan psikologis pemilih dengan partai (identitas partai) sangat rendah. Tidak ada loyalitas pada partai. Kondisi politik dan penegakan hukum dirasakan semakin memburuk dan pemerintah yang berkuasa berasal dari partai utama. Swing voter pada partai tersebut karena imbas dari keadaan politik dan penegakkan hukum yang memburuk tersebut. Keadaan ini juga berimplikasi pada tingkat ketidakpuasan atas kinerja presiden. Mayoritas pemilih tidak puas dengan kinerjanya. Terjadi skandal politik yang menimpa partai utama, dan mendapat perhatian publik secara luas. Kecenderungan pemilih terbuka, rasional, dan bereaksi terhadap situasi yang dialami, yakni menghukum perilaku partai yang buruk, dan kemudian menunggu, atau menjatuhkan pilihan pada partai yang dinilai memberikan harapan. Ini terjadi terutama pada pemilih kelas menengah, yang jumlahnya semakin besar. Selain itu, juga terjadinya mobilisasi politik yang tidak seimbang antarpartai. Partai yang lebih unggul dalam mobilisasi dapat mengambil pemilih mengambang, terutama pemilih kelas menengah ke bawah.

\section{Profile pemilih partai menurut mengikuti \\ berita tiap hari lewat media massa ... (\%)}

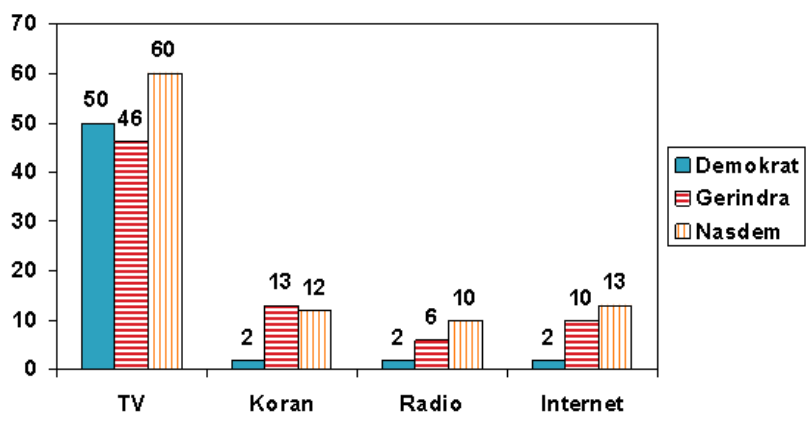

Gambar 10 Profil Pemilih Partai berdasarkan Media

Intensitas mengikuti berita lewat media massa merupakan indikator dari kelas menengah, terutama media massa yang menyajikan berita secara lebih dalam seperti surat kabar, dan internet. Terlihat bahwa proporsi pemilih Gerindra dan Nasdem yang mengakses berita tiap hari lebih besar dibanding pemilih Demokrat sekarang, terutama berita lewat surat kabar, radio, dan Internet. Ini mengindikasikan bahwa kelas menengah yang sebelumnya mendukung Demokrat berpindah ke dua partai yang relatif baru ini. Ini juga menjelaskan alasan dua partai tersebut, setelah Golkar, paling banyak menyerap pemilih Demokrat 2009 itu.

\section{SIMPULAN}

Perubahan politik secara sangat berarti telah menandai Indonesia pada zaman reformasi sekarang ini. Tiga kali pemilu menghasilkan tiga partai berbeda sebagai pemenang suara terbanyak. Ini mengindikasikan bahwa rakyat Indonesia sangat terbuka terhadap perubahan meskipun dalam ketidakpastian apakah perubahan itu akan membuat politik Indonesia menjadi lebih baik atau tidak. Perubahan politik ini kemungkinan akan berlanjut pada Pemilu 2014 seiring dengan semakin negatifnya sentimen rakyat terhadap keadaan politik Indonesia secara umum sekarang ini, dan belum 
terlihat adanya indikasi kenaikan dukungan yang cukup konsisten pada sebuah partai politik utama pasca-pemilu 2009.

Potensi swing voter sangat besar, dan ini bisa mengubah peta kekuatan partai politik 2014. Swing voter terbesar diperkirakan akan terjadi pada Partai Demokrat. Sekitar 65\% pemilih Demokrat 2009, sebagai partai paling besar, telah berpindah ke partai lain sekarang ini. Sumber utama swing voter Demokrat adalah skandal korupsi yang menimpa sejumlah kader utamanya, bukan karena kemarahan pemilih atas kondisi ekonomi nasional atau kinerja presiden sebab persepsi atas kondisi ekonomi nasional dan kinerja presiden secara umum positif.

Publik umumnya mengikuti berita dan opini skandal korupsi kader Demokrat lewat media massa, dan merasa yakin bahwa berita dan opini itu benar. Partai yang mendapat swing voter lebih besar adalah partai-partai yang lebih unggul dalam mobilisasi pemilih, yakni Golkar, NasDem, dan Gerindra. Golkar terlihat unggul dalam mobilisasi darat secara nasional, dan menyedot swing voter Demokrat di luar Jawa yang secara tradisional merupakan basis Golkar.

NasDem dan Gerindra cukup menonjol dalam mobilisasi pemilih lewat udara, lewat media massa. Kedua partai ini menarik swing voter Demokrat yang berlatar belakang kelas menengah yang lebih intensif mengikuti berita nasional.

Walaupun Pemilu 2014 masih lama, belajar dari pengalaman pemilu sebelumnya, perubahan peta kekuatan politik sangat besar kemungkinannya. Pada pemilu 1999 PDIP adalah partai yang mendapat suara paling besar (34\%), kemudian diganti Golkar pada 2004 (22\%), dan selanjutnya diganti Demokrat pada 2009 (21\%). Melihat pola ini, ada peluang munculnya partai lain yang mengambil alih posisi Demokrat pada 2014 nanti. Bisa jadi Golkar kembali, atau PDIP. Atau, partai lain yang potensial adalah Gerindra karena dinamikanya cukup terlihat sekarang. Atau bisa jadi NasDem, yang merupakan partai baru tetapi sekarang sudah berada pada posisi terkuat di kelompok partai tengah. Keadaan NasDem ini tidak pernah dialami partai baru sebelumnya, baik Demokrat maupun PKS menjelang Pemilu 2004, maupun Gerindra dan Hanura menjelang Pemilu 2009.

\section{DAFTAR PUSTAKA}

BPS. Rilis Data BPS. Diakses dari http://bps.go.id

Detik. (15 Maret 2013). Tingkat Golput dalam Pilgub Sumut Lebih dari 50 Persen. Diakses dari http://news.detik.com/read/2013/03/15/203521/2195547/10/tingkat-golput-dalam-pilgubsumut-lebih-dari-50-persen

KPU. Rilis Data KPU. Diakses dari http://data.kpu.go.id

Lembaga Survei Indonesia. (2012). Perubahan Politik 2014: Tren Sentimen Pemilih pada Partai Politik.

Mujani, S. (2012). Kecenderungan Swing Voter Pemilih Partai Menjelang Pemilu 2014. 